\title{
LEVELS OF RESPIRATION AND OXIDATIVE PHOSPHORYLATION IN REGARD TO THE EFFECT OF TEMPERATURE OF EPAXIAL MUSCLE AND ENCEPHALON MITOCHONDRIA FROM THE ANTARCTIC FISH Trematomus newnesi
}

\author{
MALUCELLI, M.I.C. ${ }^{1}$; SUGIZAKI, M. ${ }^{2}$; SALVO, L.M. ${ }^{3}$; LUCCHIARI, P.H. ${ }^{2}$; BACILA, M. ${ }^{2}$ \\ ${ }^{1}$ Programa Antártico Brasileiro, DTI-Conselho Nacional de Pesquisas; \\ ${ }^{2}$ Pontifícia Universidade Católica do Paraná, PUCPR; \\ ${ }^{3}$ Doutoranda, Faculdade de Medicina Veterinária e Zootecnia, USP.
}

A research was carried out on the effect of temperature on the respiration and oxidative phosphorylation rates from the Antarctic fish Trematomus newnesi pectoral epaxial muscle and the encephalon isolated mitochondria, assayed in the presence of $\alpha$-ketoglutarate $(\alpha-K G)$, succinate (SUCC) or glutamate (GLU) as respiration substrates. The following values were found:with encephalon isolated mitochondria: in the presence of $\alpha-K G$, it has been found an increase in the respiration rate of 1.75 times in the interval $0^{\circ} \mathrm{C}$ and $5^{\circ} \mathrm{C}$; with glutamate and succinate of 1,71 and of 1,50 times between $0^{\circ} \mathrm{C}$ and $10^{\circ} \mathrm{C}$, respectively. For the pectoral fin epaxial muscle mitochondria there was a clear inhibition of $57,4 \%$ between $0^{\circ} \mathrm{C}$ and $10^{\circ} \mathrm{C}$ in the presence of SUCC $91,8 \%$ in the presence of $\alpha-K G$ and $31,8 \%$ in the presence of $\mathrm{GLU}$, improving, however, in a rate of $23 \%$ (SUCC), and $26 \%(\mathrm{GLU})$ between $0^{\circ} \mathrm{C}$ and $5^{\circ} \mathrm{C}$, and reducing $52 \%$ in the presence of $\alpha-K G$. From this results it is possible to establish some parameters in regard to the effect of temperature on the biochemical and physiological behavior of the mitochondria isolated from organs and tissues of Antarctic fish This research shall continue on this important process which is in the root of Antarctic fish biological mechanisms of adaptation to extreme temperatures analyzed at molecular level. From the partial results showed in this series of experiments, some values on the respiratory control (RC) were also found, measured as a rate between the state 3 of respiration, i.e, in the presence of ADP, and in state 2, of respirationr with substrate, in regard to the temperature in which the experiments were carried out. To complete these important researche, assays of respiratory control in the mitochondria preparation of organs and tissues of Antarctic and tropical fish are being carried on, in order to determine coupling or uncoupling states of the mitochondrial preparations between respiration and oxidative phosphorylation.

Key Words: respiration, oxidative, Trematomus. Apoio: CNPq/PROANTAR/SECIRM/PUCPR. 